\title{
GEAR MANUFACTURING BY USING CONVENTIONAL LATHE MACHINE
}

\author{
Gadakh Ramesh S. ${ }^{1}$, LondhePradip G. ${ }^{2}$, Shaikh Bilal A. ${ }^{3}$, ShaikhFiroj S. ${ }^{4}$ \\ ${ }^{1,2,3}$ Lecturer, Department of Mechanical Engineering, A.T.C.F.O.E, ChasAhmednagar Maharashtra, India \\ ${ }^{4}$ Lecturer, Department of Mechanical Engineering, G.H.R.C.O.E, ChasAhmednagar Maharashtra, India
}

\begin{abstract}
The importance of manufacturing process is that without it no product reach to customer satisfaction. Hence for the Engineers it is importanceto covert design into actual product and this one possible only when we go through suitable manufacturing process. Hence manufacturing process is value addition process in which raw material gets converted into finished goods. Gear is important element of mechanical power transmission. It is manufactured by many process such as casting, milling, Hobbing and shaping. All these Manufacturing having its own importance. Among these manufacturing milling is preferred most for job or small amount of production. This milling machine is costly so we have making a new attachment which make gear when installed on lathe carriage. This one is cheap device hence avoids dependency on costly milling machine for job production.
\end{abstract}

Keywords: Gear, Milling, Lathe Machine, Attachment, Economy.

\section{INTRODUCTION[1]}

Gears are toothed wheel usedto transmit power for small distances. It is positive types of drive and mostly preferred in machines. The important use of various type of gears are as follows-

- Spur gear-sliding mesh gear box, machine tool gearbox

- Helical gear- automobile gear box

- Rack \& pinion- lathe carriage, steering gear box

- Worm \& worm wheel- wiper mechanism, material handling equipments gear box, steering gear box

- Bevel gear- automobile differential gear box

- Spiral gear-drives in textile machineries

\subsection{Manufacturing of Gears}

The various steps of gear manufacturing are:

1. Blank preparation

2. Heat treatment of blank

3. Turning of gear blank with desired face width and major diameter.

4. Gear tooth cutting by suitable manufacturing process.

5. Suitable Gear finishing process

6. Heat treatment of gear

7. ID and face grinding of gear

\subsection{Types of Gear Manufacturing[1][2]}

\subsubsection{Manufacture of gears by rolling}

The spline on the shaft is created by cold rolling of shaft between two circular dies as shown in fig-1. Such a small tooth thickness is difficult to achieve by other process hence this type of method is preferred.[2]

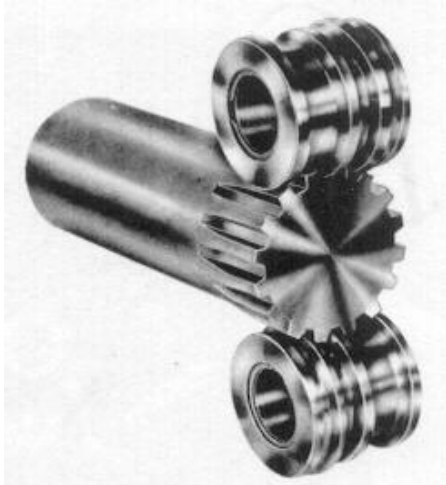

Fig-1: Manufacture of gears by rolling

\subsubsection{Extrusion Process}

Accurate gears of soft material are done by extrusion process which saves the further heat treatment process. A bar is extruded through a forming die and cavity shape is like gear tooth profiles hence after coming out bar from cavity achieve the shape of exact gear. By cutting this extruded bar with desired face width we achieve the gear. This process saves other operations also hence suited for mass production.

\subsubsection{Wire EDM}

In wire cut EDM process thin copper or brass wire is used instead of electrode. Potential difference is created between work piece and wire and due to this across gap electric field gets generated and gap breaks and current flow through it and heat is generate. Due to this work piece vaporize after melting. With Numerical control of table movement the shape of work piece is controlled and we get desired accurate and finished gear. This method suitable for external as well as internal gear.[1][2] 


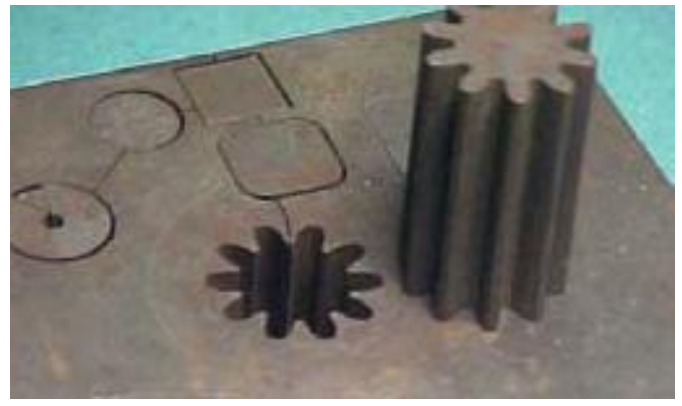

Fig-2: Gear by using wire EDM

\subsubsection{Form milling}

From figure cutter is mounted on arbor with its axis right angle to work piece. Indexing plate provided for indexing movement of work piece. In single pass one tooth is finished hence it is time consuming process and suitable for job production [2].

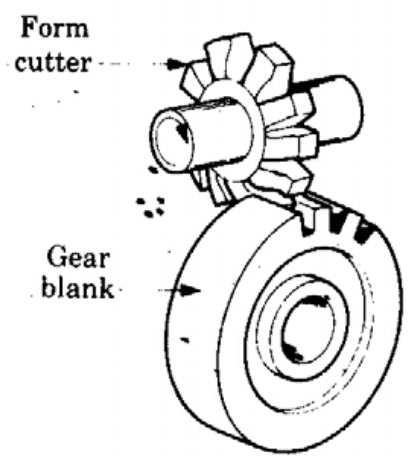

Fig-3: Gear Cutting by Milling Process

\subsubsection{Hobbing}

The gear cutter named as hob is rotated at suitable speed and feed into rotating gear blank up to required thickness.

This method is fast compared to milling process hence mostly suitable for mass production [2].

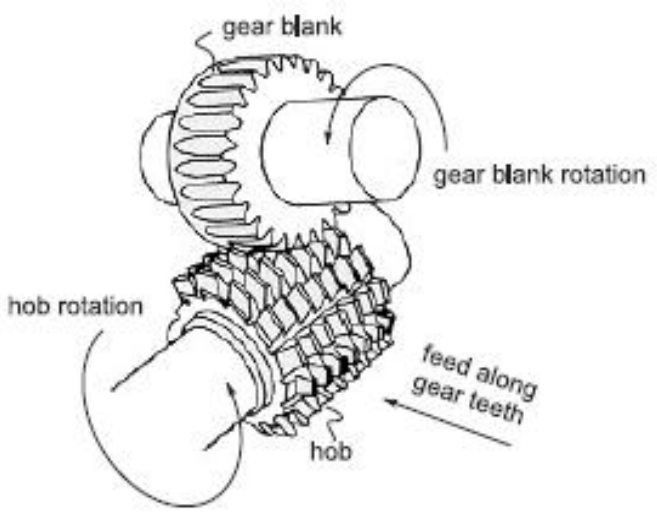

Fig-4:GearCutting by Hobbing Process

\subsubsection{Shaping}

The cutter shape in this type is like a pinion which is mounted vertically and reciprocates up and down. During this reciprocating action of cutter workpiece is also rotate and generates tooth profile on work piece. This method is suitable for mass production and external as well as internal gear manufacturing [2].

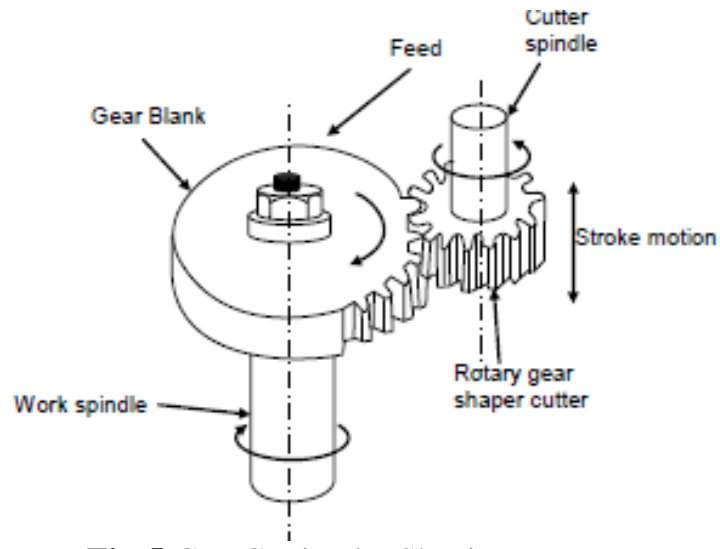

Fig-5:GearCutting by Shaping Process

\subsection{Need of Project}

We have seen all above gear manufacturing processes from that we conclude that 3 methods are mostly used for gear which one are as follows

1. Gear milling -simple and for JOB production

2. Gear hobbing-for mass production

3. Gear shaping- mass production \& internal gear manufacturing

All above process require costly machine tool and which one is not affordable for small scale industry or workshop. When in some cases we don't get the desire gear suitable for our requirement. Then our problem is that we have to find out such method or technique which can make teeth of gear without using such a costly machine tool.

Hence our need is we have to make any cheap alternative method for gear production

\section{DIFFERENT TYPES OF GEAR ATTACHMENT ON LATHE MACHINE}

\subsection{Taper Turning Attachment On Lathe Machine}

For production of taper turning on work-piece this attachment is used.[3]

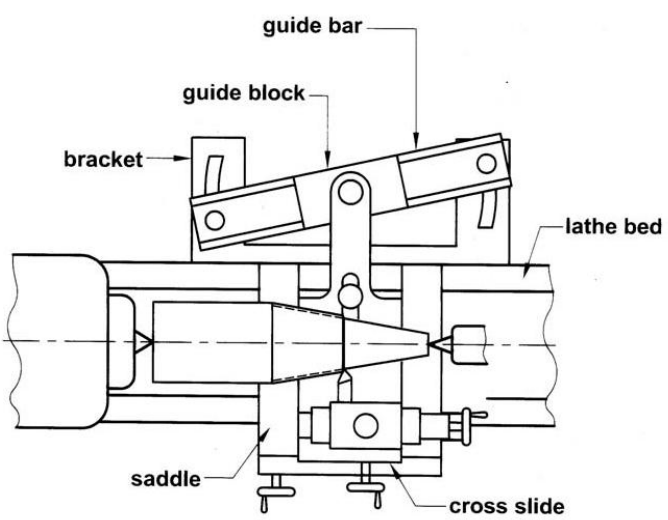

Fig-6:Taper Turning Attachment 


\subsection{Drilling Attachment On Lathe Machine}

The following attachment is used for production of slot on round or square bar with the help of drill which is fixed in lathe chuck. The w/p is feeded by motion provided to lathe carriage

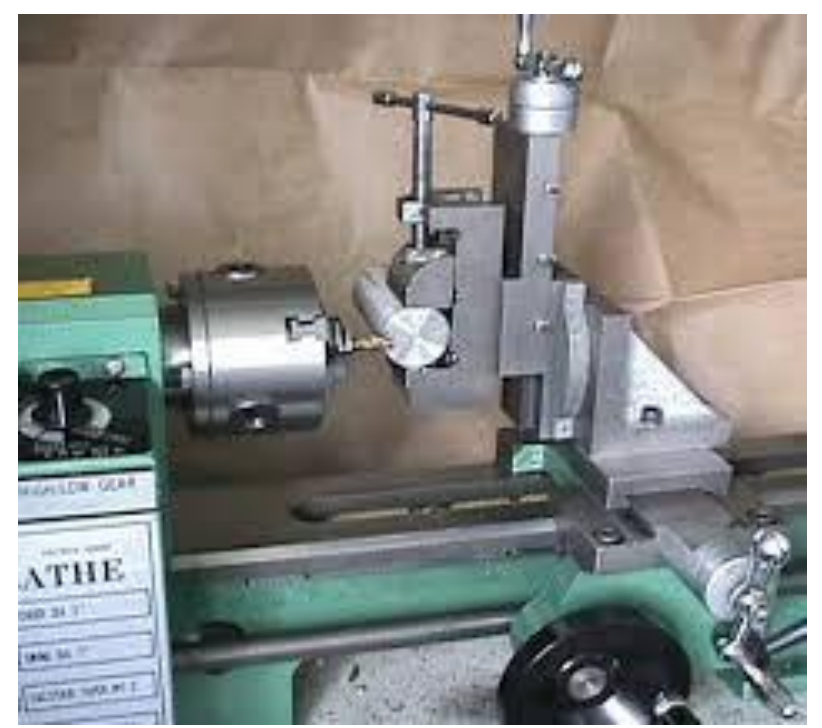

Fig-7: Attachment on lathe machine for slot

\subsection{Grinding Attachment On Lathe Machine}

The following attachment is used for finishing the round work piece with the help of grinding wheel which is feeded by motion provided to lathe carriage. The circular work piece is hold between the centers of lathe machine.[3]

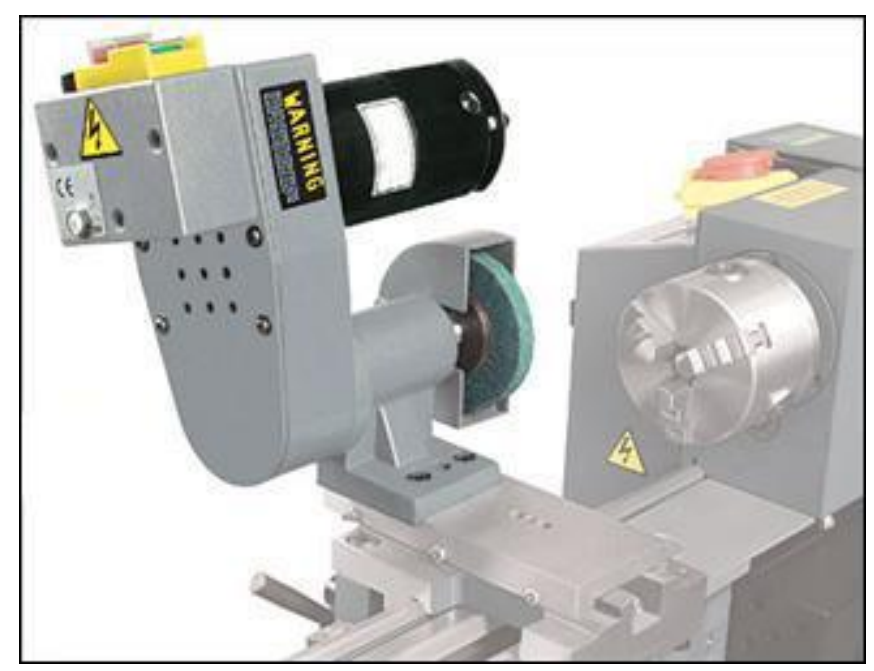

Fig-8: Attachment on lathe machine for grinding

\subsection{MILLING ATTACHMENT}

In milling attachment on lathe machine the milling cutter with arbor is held between the two centers of lathe machine hence rotary motion of cutter is possible here. The work piece with suitable fixture is mounted on lathe carriage and feeded against milling cutter. By this method we can achieve groove, slots, keyway on the work piece[3].

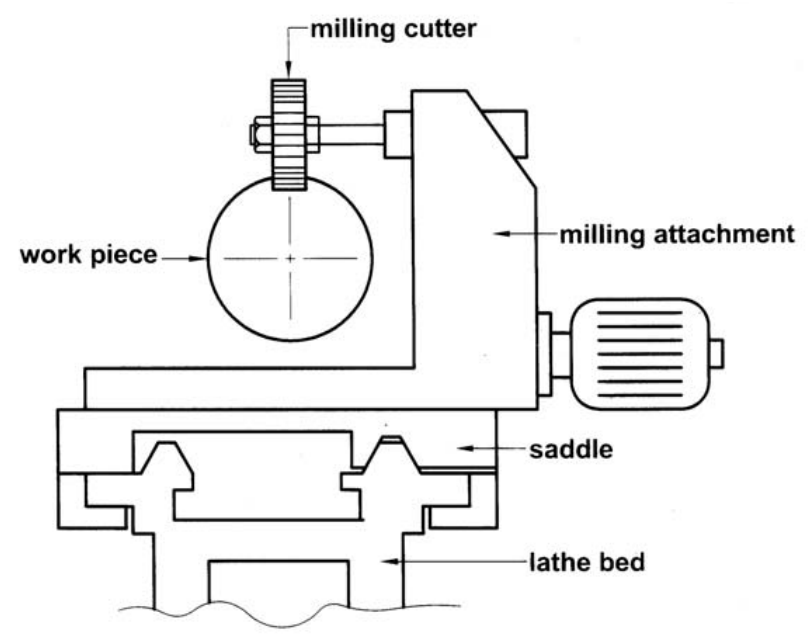

Fig-9: Attachment on lathe machine for milling

\section{CONSTRUCTION}

\subsection{Componentsand Its Function}

1. C channel: $C$ Channel used for sliding metal block 2. Metal Block: In metal block shaft is rotated according Indexing of mechanism

3. Tightening Nut And Bolt: This help in fixing the position metal block in $\mathrm{C}$ channel

4. Stepped Shaft: This shaft used for fixing gear blank and also indexing mechanism fixed on it.

5. Spacer: It connects Indexing plate to the metal block.

6. Indexing plate:To cut the gear tooth after equal interval indexing mechanism is used.

7. Engaging Plate with screw: Permit Indexing

8. Gear Blank: Tight by nut on the stepped shaft

9. Top Plate: It provide Locking arrangement.

10. Bottom Plate:This plate is fitted with carriage plate Hence size is like that o lathe carriage

11. Tightening Nut: lock indexing plate and gear blank.

12. Gear cutter with arbor: Gear milling cutter is fixed on arbor with the help of square key. This arbor is centered between two lathe machines center.

\section{WORKING}

Followingfig.helpful for understanding the working of project. Working is similar to that of previous attachment i.e. Gear milling cutter with arbor is hold between two center of lathe machine and when power given to lathe machine it starts rotating which we want the cutting tool motion. The work piece is fitted on the Stepped shaft and this shaft is rotate in metal block when indexing is performed while cutting it remains in rest position. The indexing mechanism which important for gear tooth production after equal interval. The shaft is in metal block can also be moved in vertical direction according to diameter of workpiece and there is nut bolt arrangement is provided for locking of metal block in $\mathrm{C}$ channel. Feeding motion for this shaft is provided by the rotating the carriage wheel against the motion of cutting tool. Hence all motion is available for this attachment for gear making purposes. And we make here Spur as well as helical gear by using this 
attachment. For Production of helical gear we need tilting of bottom plate (as that of Taper turning)according to helix angle of gear. For Production of next teeth we have to disengage the screw and by rotating the shaft in metal block upto next hole of indexing plate so that we lock this position for gear cutting by engaging the screw in that hole of indexing plate.

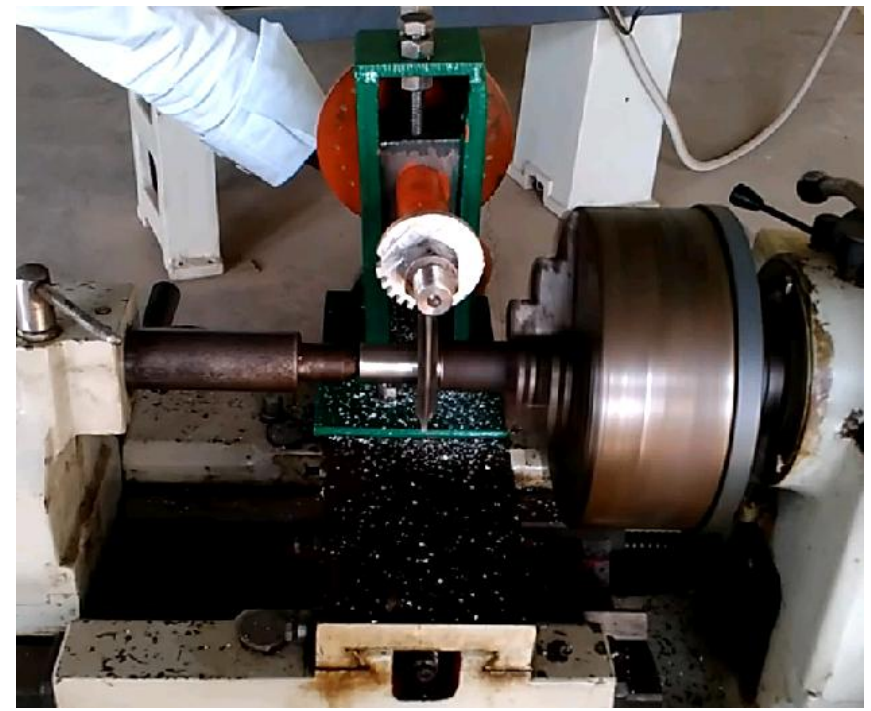

Fig-10: Working Of Gear manufacturing by using conventional lathe machine

\section{SELECTION \& DESIGN CRITERIA}

\section{$5.1^{\prime} \mathrm{C}$ ' Channel}

Material : Hardened mild steel

'c' channels of above materials are easily available in metal shop compared to Al metal also cutting is not possible of other material as per our requirement.

Height $=230 \mathrm{~mm}$

Distance between carriage plate to center of chuck or cutter arbor is $90 \mathrm{~mm}$ for our lathe machine. If we keep height of shaft which hold work piece the for max. $45 \mathrm{~mm}$ rad. Of milling cutter, the height of w/p on shaft must be $90-45=35$ mm dia.

So when we provide w/p below the milling cutter Such a less dia shaft is produced which is not genrally used and if we want to increase the dia. Range of $w / p$ the we must have to provide $w / p$ above the milling cutter.

Suppose our w/p is above milling cutter then for max. $45 \mathrm{~mm}$ cuutter dia. And upto $65 \mathrm{~mm} \mathrm{w} / \mathrm{p}$ dia. The height of carriage plate to centre axis of w/p is $=90 \mathrm{~mm}+45 \mathrm{~mm}+65 \mathrm{~mm}=200 \mathrm{~mm}$.

Now height of channel also depends on metal block height. Assuming our metal block height is $70 \mathrm{~mm}$ then height of channel $=200+(60 / 2)=\mathbf{2 3 0} \mathbf{m m}$.

Width in F.V. $=60 \mathrm{~mm}$
From front view width is that length on which a metal block can slide. And as per previous assumption we have taken this length for metal block=60 $\mathrm{mm}$

And also such dimension also available in market for channel so Width in F.V. of ' $c$ ' channel $=\mathbf{6 0} \mathbf{m m}$.

Width in S.V. $=12.5 \mathrm{~mm}$

If shaft dia. Assuming $35 \mathrm{~mm}$ then for that differnce between two flanges must be grater than $35 \mathrm{~mm}$ when this channel is welded to bottom plate of assembly.

$2 \mathrm{x}+35=60 \quad 2 \mathrm{x}$ means mean width of two web

Hence $\mathrm{x}=\mathbf{1 2 . 5}$

\subsection{SHAFT DESIGN}

Material : mild steel

Cost of $\mathrm{Al}$ rod is high, also not easily available

Length $=272 \mathrm{~mm}$

$40 \mathrm{~mm}=$ for $1^{\text {st }}$ locking nut width $(20 \mathrm{~mm})+$ engaging plate $(4$ to $5 \mathrm{~mm})+2$ nd locking nut width $(20 \mathrm{~mm})+$

$80 \mathrm{~mm}=$ metal block and web length $(60 \mathrm{~mm})+$ for spacer length $(20 \mathrm{~mm})$

$100 \mathrm{~mm}=$ cutter advancement for full depth of $\mathrm{w} / \mathrm{p}$ if we assumed cutter of dia. $45 \mathrm{~mm}$ then $(55 \mathrm{~mm}) \mathrm{mm}$ +assuming free advancement of cutter from $\mathrm{w} / \mathrm{p}=45 \mathrm{~mm}$

$52 \mathrm{~mm}=\mathrm{w} / \mathrm{p}$ width (upto $20 \mathrm{~mm}$ ) + lock nut width (upto 20 $\mathrm{mm}$ )+allowance

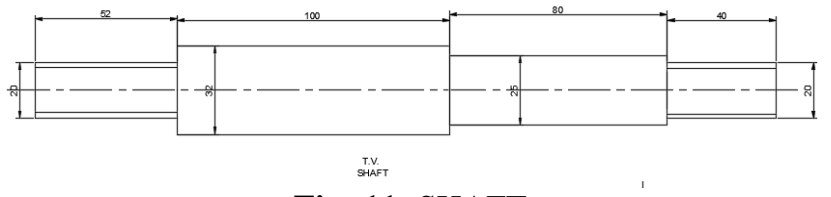

Fig.-11: SHAFT

\subsection{METAL BLOCK}

Material : mild steel

Cost of $\mathrm{Al}$ block is high, also not easily available and cutting is difficult for large width.

Dimension $=65 \times 65 \times 60 \mathrm{~mm}^{3}$

Wo oly need dimension of $60 \mathrm{~mm}$ block because 'c' channel guide space is available is of $60 \mathrm{~mm}$ for one dimension.

For othe two dimension we provide it above 60 bexause if we take shaft dia. Upto $35 \mathrm{~mm}$ then flanhe width of $\mathrm{c}$ channel in side view become $12.5 \mathrm{~mm}$ which becomes cmforatable for machining.

In that block we have to insert a shaft whose dia. Below larger value of dia. Of shaft because same dia. Value of shaft can cause linear motion of shaft in metal block due to cutting force of cutting tool.

Hence to avoid this as like a collar we have to provide large dia. Outside the metal block. We tale $\mathbf{2 5} \mathbf{m m}$ dia. For hole because we have available $25 \mathrm{~mm}$ largest drilling cutter after largest dia. of w/p. 

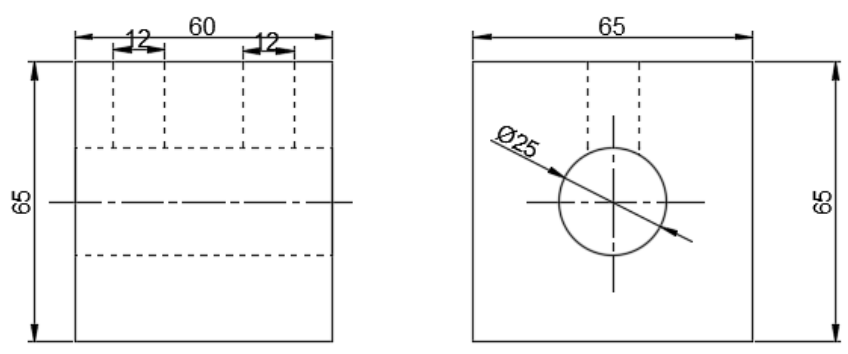

METAL BLock

s. v.

Fig.-12:Metal Block

\subsection{BOTTOM PLATE}

This plate is fitted with carriage plate Hence size is like that o lathe carriage.

The two holes provided on thar of dia. 10mm because lathe carriage head dia. is $9 \mathrm{~mm}$.

The distance between that two hole is $96 \mathrm{~mm}$ which is circumference of slot present on plate of lathe machines carriage.

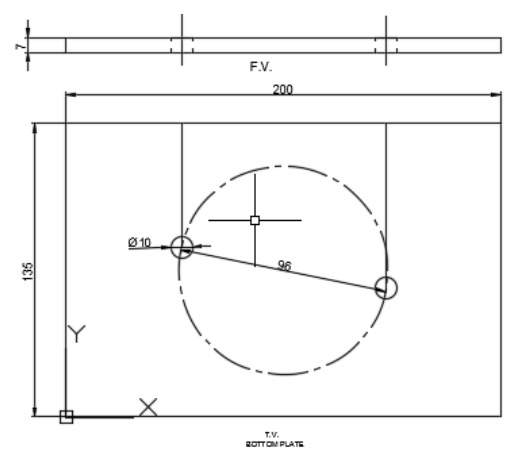

Fig.-13:Bottom Plate

\subsection{ASSEMBLY}

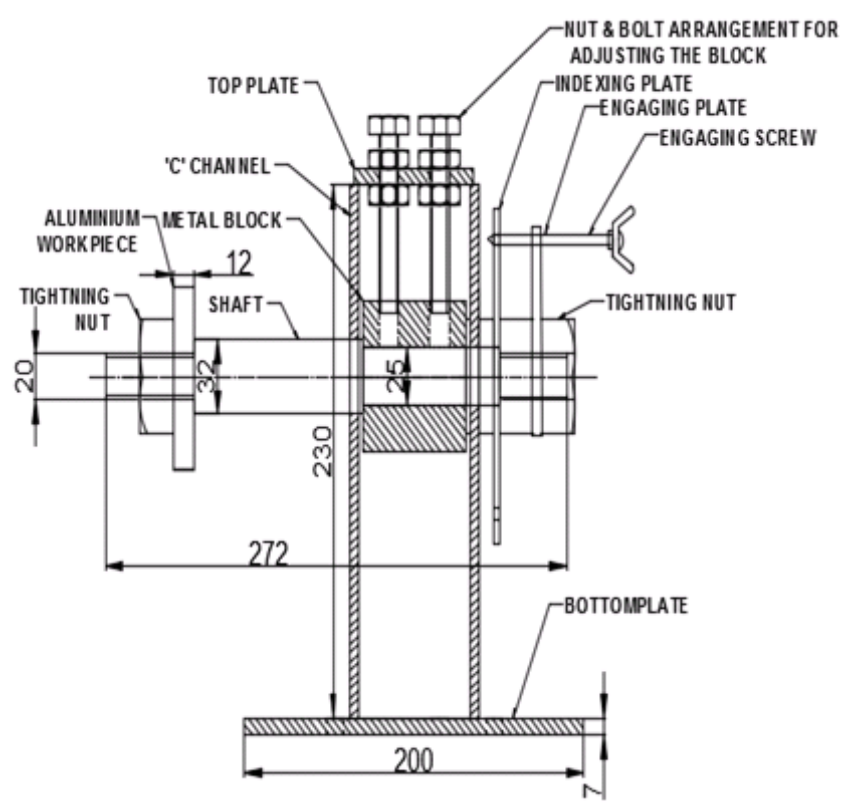

Fig-14: Gear manufacturing by using conventional lathe machine

\section{COST ESTIMATION}

\subsection{BROUGHT OUT MATERIAL COST}

Table-1: Brought out material cost

\begin{tabular}{|c|c|c|c|c|}
\hline S.R. & NAME & SPECIFICATION & QTY & COST \\
\hline 1 & SHAFT & $\begin{array}{l}\text { 32mm dia. \& } \\
500 \mathrm{~mm} \text { length }\end{array}$ & 1 & 300 \\
\hline 2 & C channel & Length $460 \mathrm{~mm}$ & 1 & 200 \\
\hline 3 & $\begin{array}{l}\text { Milling } \\
\text { cutter }\end{array}$ & $\begin{array}{l}2 \mathrm{~mm} \text { module } \& 25 \\
\mathrm{~mm} \text { bore }\end{array}$ & 1 & 1500 \\
\hline 4 & $\begin{array}{l}\text { Al round } \\
\text { bar }\end{array}$ & $\begin{array}{l}60 \mathrm{~mm} \text { dia\& } \\
\text { Length }=30 \mathrm{~mm}\end{array}$ & 1 & 150 \\
\hline 5 & Nut \&bolt & M11 & 2 & 40 \\
\hline 6 & Nut & M25 & 3 & 75 \\
\hline 7 & $\begin{array}{l}\text { Engaging } \\
\text { screw }\end{array}$ & M4 & 1 & 10 \\
\hline 8 & Wing nut & & 1 & 20 \\
\hline 9 & $\begin{array}{l}\text { Sheet } \\
\text { plate }\end{array}$ & $\mathrm{L}=270 \mathrm{~mm}, \mathrm{t}=7 \mathrm{~mm}$ & 1 & 250 \\
\hline 10 & key & $4 \mathrm{mmX} 2 \mathrm{~mm}$ & 1 & 20 \\
\hline 11 & $\begin{array}{l}\text { Metal } \\
\text { block }\end{array}$ & $60 X$ scrap & 1 & 400 \\
\hline \multicolumn{4}{|c|}{ Total } & $2965 /-$ \\
\hline
\end{tabular}

\subsection{MANUFACTURING PROCESSES COST}

Table-2: Manufacturing processes cost

\begin{tabular}{|l|l|l|}
\hline Sr. No. & Name Of Process & Cost in Rs \\
\hline 1 & C channel & 205 \\
\hline 2 & Metal block & 370 \\
\hline 3 & Indexing plate & 370 \\
\hline 4 & Shaft & 390 \\
\hline 5 & Spacer & 50 \\
\hline 6 & $\begin{array}{l}\text { Engaging plate with } \\
\text { screw }\end{array}$ & 100 \\
\hline 7 & Gear arbour & 110 \\
\hline 8 & Gear Blank & 50 \\
\hline 9 & Top plate & 90 \\
\hline 10 & Bottom plate & 60 \\
\hline 11 & Assembly & 110 \\
\hline & Total & $\mathbf{1 9 0 5 / -}$ \\
\hline
\end{tabular}

BROUGHT OUT MATERIAL COST=

2965/MANUFACTURING PROCESSES COST $=$ 1905/- 


\section{FEATURES}

\subsection{Advantages}

1. Simple assembly

2. Easy installation on lathe machine

3. spur, helical \& bevel gear can cut by this

4. cost of milling $\mathrm{m} / \mathrm{c}$ is saved

5. easily available by manufacturing

6. simple to operate.

\subsection{Disadvantages}

1.Only for job production i.e. in less quantity

2. w/p height is limited to radius of $45 \mathrm{~mm}$.

\subsection{Area of Application}

1. Manufacturing of spur, helical and bevel gear in small workshop where milling $\mathrm{m} / \mathrm{c}$ is not affordable.

\section{FUTURES SCOPE}

In this project we making attachment on lathe machine. We can also make gear on drilling machine because it present in all workshop and fabrication shop easily And rotating motion is available on spindle of drilling machine. Only there is problem in feeding of work piece against cutter. By improving drilling table we can also achieve this one.

\section{CONCLUSIONS}

Hence from this project we conclude that for job production of gear this attachment really useful for small workshop and this is good alternative for milling machine from this arrangement we can produce spur, helical as well as bevel gear. This machine having advantages such as Simple assembly, Easy installation on lathe machine, spur, helical \& bevel gear can cut by this, cost of milling $\mathrm{m} / \mathrm{c}$ is saved, easily available by manufacturing.

\section{ACKNOWLEDGEMENT}

We with great pleasure take this opportunity to express my deep sense of gratitude towards AdsulCollege of Engineering, Chas Ahmednagarfor allowing us to do the dissertation work and all other library and laboratory facilities like lathe machineproviding for testing purposes.We also would like to thank Machine shop instructor Thange P. K., Department of Mechanical Engineering for his valuable guidance and constantinspiration during the completion of this paper and project. We express our special thanks to students of Department of Mechanical Engineering for their Interestin this idea of project which comes in existence only for them. Lastly, I would like to thank all those who helped we directly or indirectly.

\section{REFERENCES}

[1]. Valery Marinov, Manufacturing Technology,Kendall Hunt Publishing Company, 2010
[2]. Version 2 ME, IIT Kharagpur,Lesson 32 Manufacturing of Gears

[3]. Version 2 ME, IIT KharagpurModule 4 General Purpose Machine Tools

[4].V.B.Bhandari, Design of machine elements, Third edition, Tata McGraw Hill Education private limited, New Delhi.

[5]. R.S. Khurmi\&B.C.Gupta, Theory of Machines, Eurasia publishing house pvt ltd., First edition, 1976. 